\title{
Tuna satak bathi sanak: integrasi kearifan lokal budaya Jawa dalam pembelajaran ilmu sosial
}

\author{
Oleh:
}

Yuliyanto

Madrasah Aliyah Negeri 4 Sleman Yogyakarta

pakguruyuli.yy@gmail.com

submitted: 07-02-2021 revised: 15-03-2021 accepted: 18-03-2021

\begin{abstract}
Abstrak
Tuna satak bathi sanak merupakan kearifan lokal masyarakat Jawa yang mencerminkan nilai-nilai luhur kerja sama dan gotong royong pada masyarakat Jawa. Konsep tersebut dipakai oleh para pedagang untuk menarik para pembeli, rugi sedikit tidak mengapa asalkan bertambah saudara. Metode penelitian yang digunakan adalah penelitian deskriptif dengan pendekatan kualitatif. Pengumpulan data dilakukan dengan metode studi pustaka pada dokumen-dokumen tertulis berupa buku, artikel, hasil penelitian, jurnal dan artikel media yang terkait dengan konsep tuna satakbathi sanak serta relevansinya dengan pembelajaran ilmu sosial di sekolah. Hasil penelitian yang menunjukkan bahwa integrasi nilai kearifan lokal tuna satak bathi sanak dapat dilakukan dengan strategi mengajak siswa mengobservasi penerapan nilai tersebut di tengah masyarakat, kemudian siswa mendiskusikan di kelas, dan menggali potensi-potensi kearifan lokal lain yang bisa dikembangkan. Kata kunci: tuna satak bathi sanak, kearifan lokal budaya Jawa, perdagangan
\end{abstract}

\begin{abstract}
Tuna satak bathi sanak is a Javanese local wisdom reflects the noble values of cooperation and mutual cooperation in Javanese society, especially used by traders to attract buyers, a little loss is tolerable as long as you get more relatives. The research method used is descriptive research with a qualitative approach. Data collection was carried out by using the literature study method on written documents in the form of books, articles, research results, journals and media articles related to mental disabilities and their relationship with social studies learning. The explanation of the results of the study was carried out descriptively. Data were analyzed using descriptive methods with a theoretical approach and concepts in accordance with social studies learning. The results obtained are if the integration of local wisdom values of tuna satak bathi sanak can be done with a strategy of inviting students to observe the application of these values in the community, then students discuss in class, and explore other potential local wisdom that can be developed.
\end{abstract}

Keywords: tuna satak bathi sanak, Javanese local wisdom, trading 
Tuna satak bathi sanak ..... (Yuliyanto)

\section{Pendahuluan}

Kebudayaan merupakan prestasi terbesar manusia dalam mengembangkan kehidupan, dan menjadi kunci pembeda dari makhluk hidup lainnya. Kebudayaan dipandang sebagai sesuatu yang khas dengan manusia yang dihubungkan dengan keindahan, kebaikan, kecerdasan, keteraturan, dan keluhuran. Dewantara (1967: 27) menyatakan bahwa kebudayaan merupakan buah dari keadaban manusia yang bersifat tertib, indah, berfaedah, luhur, memberi rasa damai, senang, bahagia, dan sebagainya. Kebudayaan menjadi aspek yang sangat penting dalam kehidupan manusia yang dapat dijadikan parameter kemajuan. Benedict (1934) melihat kebudayaan sebagai pola pikir dan perbuatan yang terlihat dalam kehidupan sekelompok manusia, dan menjadi hal yang membedakannya dengan kelompok manusia lainnya. Para ahli umumnya sepakat bahwa kebudayaan merupakan suatu pola perilaku sebagai upaya penyesuaian diri manusia berdasarkan hal-hal yang dipelajari dari lingkungan alam dan lingkungan sosialnya. Lebih lanjut Benedict (1934: 18) menyatakan the life history of the individual is first and foremost an accommodation to the patterns and standards traditionally handed down in his community. From the moment of his birth the customs into which he is born shape his experience and behavior. By the time he can talk, he is the little creature of his culture, and by the time he is grown and able to take part in its activities, its habits are his habits, its beliefs his beliefs, its impossibilities his impossibilities.

Indonesia adalah negara yang kaya akan ragam kebudayaan, adat tradisi, Bahasa, dan alam pikiran penduduknya. Berdiri di atas pulau-pulau dengan kondisi fisik dan potensi alam yang beragam berimplikasi pada beragam pula kondisi fisik dan mental masyarakatnya. Keberagaman kebudayaan juga berpengaruh pada banyaknya ragam kearifan lokal yang eksis di tengah masyarakat. Kearifan lokal eksis dalam keseharian masyarakat sebagai keyakinan yang dibentuk oleh dinamika masyarakat secara bertahun-tahun, bahkan hingga ratusan tahun. Kearifan lokal memberikan arahan perilaku bagi anggota masyarakat untuk bisa bertahan dalam kehidupan ditengah anggota masyarakat yang lain.

Seiring dengan derasnya arus globalisasi, dinamika masyarakat semakin cepat berubah. Secara nyata, globalisasi telah menggeser nilai-nilai lokal asli masuarakat Indonesia dan menggantinya dengan nilai-nilai budaya asing. Pieterse (2004: 7) menyebutkan bahwa globalization crosses boundaries of government and business, media and social movements, general and academic interest. As a political challenge, 
it crosses the ideological spectrum and engages social movements and politics at all levels. It involves a paradigm shift from the era of the nation state and international politics to politics of planetary scope. Pergeseran ini berdampak luas tidak hanya pada masyarakat, tetapi juga pada keseimbangan lingkungan. Daniah (2016) menyebutkan bahwa kearifan lokal masyarakat secara pelan-pelan tergantikan seiring perubahan yang terjadi di masyarakat. Mempelajari nilai-nilai kearifan lokal yang sudah mapan merada di tengah masyarakat adalah hal yang jamak dilakukan. Mempelajari kearifan lokal di kelas-kelas dalam kegiatan pembelajaran juga merupakan perwujudan dari amanat Kurikulum 2013 yang menjadikan kebudayaan masyarakat sebagai salah satu kajiannya. Kearifan lokal juga perlu digali untuk menghidupkan kembali kebudayaan tradisional yang adiluhung sehingga sekolah sebagai cagar budaya untuk melakukan transmisi dan transformasi nilai dapat berlangsung dengan penuh makna. Dalam konteks demikian maka IPS merupakan salah satu pelajaran yang relevan untuk membelajarkan kearifan lokal budaya Jawa kepada peserta didik (Supardi dan Widiyastuti, 2014).

Pendidikan IPS adalah mata pelajaran yang menjadikan fenomena sosial masyarakat dan lingkungannya sebagai bahan kajian utamanya. Maka dari itu studistudi tentang integrasi kearifan lokal dalam pembelajaran IPS banyak dilakukan oleh para ilmuwan. Salah satu nilai kearifan lokal yang bisa diintegrasikan dalam pembelajartan IPS di tingkat sekolah menengah pertama (SMP) adalah nilai-nilai yang terkandung dalam ungkapan tuna satak bathi sanak. Melalui integrasi nilai kearifan lokal dalam pembelajaran IPS diharapkan siswa mampu mengembangkan ide, gagasan, berpikir kreatif, dan berargumentasi ilmiah. Karsiwan, dkk. (2017) menjelaskan bila dengan intergasi ini harapannya siswa akan mampu: a) berinisiatif mengembangkan pola pikirnya berdasar temuan yang didapatkan di dalam kelas maupun dari luar kelas; b) memberikan keleluasaan pada siswa untuk melakukan eksplorasi nailai-nilai kearifan yang ada di masyarakat lokal; c) mengembangkan proses pembelajaran yang dialogis antara guru dan siswa, serta antar siswa; d) mendorong siswa untuk mengkritisi materi pembelajaran, fakta di lapangan, dan konstruksi pengetahuan yang mereka miliki setelah melakukan pembelajaran.

Pola kehidupan manusia selalu bersifat dinamis, dimana cara hidup manusia berkembang mengikuti perkembangan zaman, dan kebutuhan hidup yang semakin kompleks. Manusia tidak lagi dapat memenuhi kebutuhan hidupnya secara mandiri. Sesuai dengan kodrat manusia sebagai mahluk sosial, manusia akan selalu 
memerlukan bantuan dan berhubungan dengan orang lain, tidak terkecuali untuk keperluan pemenuhan kebutuhan hidupnya.

Ketika manusia tidak bisa memenuhi kebutuhannya secara mandiri, maka manusia berupaya untuk memenuhinya dengan cara membeli, ataupun mencari kepada orang lain yang mempunyai barang yang mereka butuhkan. Tak ayal barter menjadi sarana yang sangat efektif untuk pemenuhan kebutuhan manakala barang yang diperlukan tidak bisa dipenuhinya sendiri. Sistem perdagangan sudah dikenal manusia sejak berabad-abad silam. Dimulai dari sistem barter sampai dengan manusia mengenal uang sebagai alat pembayaran yang sah. Barter menjadi sarana yang sangat efektif bagi manusia dalam rangka memenuhi kebutuhan hidupnya yang tidak dapat dipenuhi sendiri kala itu. Sistem barter tentunya menggunakan standar yang baku dalam sistem perdagangannya, sebagai contoh seekor ayam akan ditukar dengan menggunakan lima kilogram beras, artinya diantara kedua belah pihak tidak ada yang dirugikan dan tentunya kedua belah pihak memang saling membutuhkan barang tersebut.

Sistem perdagangan telah dikenal oleh masyarakat Indonesia sejak berabadabad silam. Perdagangan semakin maju ditandai dengan kedatangan bangsa India, Tiongkok, dan Arab. Sistem perdagangan pada masa tersebut tidak seluruhnya dilakukan dengan menggunakan mata uang, emas, atau perak sebagai alat tukar, sistem barter juga masih berlaku diantara para pedagang. Barang yang lazim diperdagangkan kala itu dari India dan Arab utamanya adalah pakaian, kain dan minyak wangi. Para pedagang Tiongkok biasa membawa barang dagangan berupa tenunan, perak, gading, manik manik, piring dan mangkuk yang biasanya berwarna biru (Poesponegoro, 2010). Komoditas lain seperti rempah rempah, beras, kayu cendana, kemenyan dan kapur barus, sebaliknya adalah komoditas utama nusantara kala itu. Dalam sistem perdagangan masa klasik, raja mempunyai sebuah hak yang dikenal dengan nama hak beli utama yaitu sebuah hak dimana raja mempunyai wewenang untuk membeli pertama kali atas barang barang yang dibawa oleh para saudagar saudagar dari India, Arab maupun Tiongkok sebelum barang-barang tersebut dipasarkan kepada masyarakat umum. Hak beli utama yang dimiliki raja ini berimplikasi bila barang-barang yang dimiliki oleh raja tidak mungkin dimiliki oleh rakyat, sehingga menambah kesan kemewahan dan elegan yang dimiliki raja dan keluarganya. 
Terlepas dari perkembangan perdagangan yang dilaksanakan antar negara pada masa kerajaan Hindu Budha, perdagangan dan sistem pasar telah dikenal luas juga dalam kerajaan. Pada masa Mataram Islam, dikenal tokoh Sultan Agung yang berhasil membawa kerajaannya menuju puncak keemasan. Sultan Agung tidak hanya piawai dalam hal politik dan strategi perang, tetapi juga raja yang ahli dalam bidang seni dan budaya. Salah satu sumbangsih Sultan Agung dalam hal budaya adalah konsep pancawara. Pancawara adalah sistem hitungan hari yang terdiri atas lima hari yang didasarkan atas kalender komariah. Lima hari tersebut adalah Legi, Pahing, Pon, Wage, dan Kliwon. Sistem pancawara ini kemudian menggantikan sistem kalender saka yang terdiri atas hari Senen, Seloso, rebo, Kemis, Jemuah, Setu dan Ngaad yang berasal dari India dengan dasar sistem kalender matahari (Poesponegoro, 2010).

Lahirnya sistem kalender pancawara kemudian lebih dikenal dengan nama hari pasaran. Kalender ini banyak digunakan oleh masyarakat Jawa pada masa itu untuk penanda hari-hari tertentu dimana masyarakat berkumpul di suatu tempat untuk mengadakan jual beli, atau pasar. Setiap pasar memiliki hari penyelenggaraan yang berbeda, terutama bagi pasar yang letaknya saling berdekatan. Hal tersebut bertujuan untuk menghindari hari pasaran yang sama, mengingat pedagang biasa berjualan berpindah-pindah pada setiap harinya. Para pedagang di masa itu umumnya adalah petani atau pekerja di sektor lain, dan berdagang bukanlah mata pencarian uatama meskipun ada diantara mereka yang memang pekerjaannya berdagang. Kebanyakan pedagang adalah petani yang menjajakkan hasil pertanian atau hasil peternakannya. Komoditas utama yang diperdagangkan adalah hasil bumi, ternak, pakaian, alat-alat pertanian, bahan makanan pokok, dan makanan jadi.

Begitu penting makna pasar bagi masyarakat Jawa. Pasar tidak hanya sekedar pusat kegiatan ekonomi masyarakat. Pasar juga pusat berkembangnya budaya. Pada masa tersebut, teknologi komunikasi belum berkembang sehingga salah satu kesempatan bagi masyarakat untuk berkumpul melakukan interaksi adalah pada kegiatan yang mereka lakukan di pasar. Pasar tradisional adalah simbol ekonomi rakyat kecil, ada simbol kesederhanaan dan kesahajaan di sana. Maka penulis tidak setuju bila pasar tradisional diubah menjadi pasar modern dengan menggusur para pedagang kecil. Masyarakat Jawa memandang bahwa transaksi perdagangan bukan hanya sekedar proses jual beli namun lebih dari itu, perdagangan sianggap sebagai proses ritme romantis kehidupan masyarakat Jawa dalam memenuhi kebutuhan hidupnya. Lobi antara pedagang dan pembeli dalam sistem perdagangan masyarakat 
Tuna satak bathi sanak ..... (Yuliyanto)

Jawa mutral sangat diperlukan termasuk dalam urusan menjajakan barang dagangan ana rega ana rupa (Pitoyo, 2008). Setelah terjadi kesepakatan harga maka pembayaranpun dilakukan dan si pedagang akan melepaskan dagangannya setelah dirasa memperoleh untung yang cukup.

Pada kenyataan di lapangan tidak semua transaksi perdagangan akan memberikan keuntungan bagi pedagang, tidak jarang pedagang hanya memperoleh untung yang pas-pasan atau bahkan kerugian. Sebagai contoh ketika pedagang membeli barang dagangan dengan harga 1000, maka dengan harapan pedagang tersebut dapat menjual barang dagangannya dengan harga diatas 1000. Tetapi penjualan tidak selalu berjalan lancar, kadang pedagang tidak bisa menjual barang sesuai dengan target yang telah direncanakan. Termasuk ketika berhadapan dengan calon pembeli yang daya belinya di bawah harga yang dia tetapkan, ataupun calon pembeli yang memiliki hubungan akrab dengan pedagang. Dalam kondisi ini pedagang bisa melepas barang dagangannta dengan harga yang lebih rendah. Tuna sathak bathi sanak, adalah kata bijak yang mencerminkan kondisi tadi. Memiliki makna tuna setitik ora popo nanging tambah anggone paseduluran, rugi sedikit tidak mengapa, asalkan tambah persaudaraan. Ungkapan Jawa inilah yang kemudian menjadi salah satu spirit khas, penyemangat para pedagang di pasar-pasar tradisional Jawa hingga saat ini (Sumodiningrat, 2017). Hal yang menarik dalam konsep kearifan lokal ini, adalah nilai-nilai yang terkandung dalam ungkapan tersebur dijadikan strategi bagi pedagang untuk mencari pembeli sekaligus menambah koneksi persaudaraan. Melalui strategi ini diharapkan suatu hari nanti ketika pembeli kembali datang ke pasar untuk berbelanja, maka pembeli ini akan berbelanja kepada pedagang yang dianggapnya bersaja, memberikan kesan baik, dan ramah pada kesempatan sebelumnya. Ikatan persaudaraan ini biasa terjalin lebih jauh sampai ranah personal.

Nilai-nilai dalam kearifan lokal ini sejalan dengan nilai-nilai yang ditanamkan pada pembelajaran IPS di sekolah-sekolah. Sesuai ranah kajian pendidikan IPS yang disampaikan oleh Supardi dan Widiastuti (2014) yang mencakup kajian berbagai fenomena kehidupan dan masalah sosial yang diorganisasikan dan disajikan secara ilmiah pedagogi dan psikologis. Pada pembelajaran IPS siswa juga diarahkan untuk dapat menjadi warga negara Indonesia yang demokratis, bertanggungjawab, dan warga dunia yang cinta damai. Dengan penamaman nilai kearifan lokal melalui integrasi nilai-nilai dengan pembelajaran diharapkan siswa dapat merefleksikan dalam diri mereka bahwa masyarakat tempatnya lahir dan bertumbuh adalah 
masyarakat yang menjunjung tinggi nilai-nilai karakter maka siswa juga bisa menginternalisasikannya dan menjadikannya sebagai kebiasaan dalam kesehariannya. Adanya kesamaan keselarasan antara nilai yang terkandung dalam spirit tuna satakbathi sanak dan tujuan penyelenggaraan pendidikan IPS di sekolah, sekiranya perlu dilakukan kajian yang lebih mendalam. Kajian yang dilakukan untuk mengetahui bagaimanakah nilai-nilai dalam kearifan lokal ini berjalan selaras dengan pendidikan yang secara formal diamantkan untuk diberikan kepada siswa di sekolah.

\section{Metode Penelitian}

Metode yang digunakan dalam kajian ini menggunakan metode atau pendekatan kepustakaan (library research). Studi pustaka atau kepustakaan dapat diartikan sebagai serangkaian kegiatan yang berkenaan dengan metode pengumpulan data pustaka, membaca dan mencatat serta mengolah bahan penelitian (Zed, 2003:3). Dalam penelitian studi pustaka setidaknya ada empat ciri utama yang penulis perlu perhatikan diantaranya: Pertama, bahwa penulis atau peneliti berhadapan langsung dengan teks (nash) atau data angka, bukan dengan pengetahuan langsung dari lapangan. Kedua, data pustaka bersifat siap pakai, artinya peneliti tidak terjung langsung ke lapangan karena peneliti berhadapan langsung dengan sumber data yang ada di perpustakaan. Ketiga, bahwa data pustaka umumnya adalah sumber sekunder, dalam arti bahwa peneliti memperoleh bahan atau data dari tangan kedua dan bukan data orisinil dari data pertama di lapangan. Keempat, bahwa kondisi data pustaka tidak dibatasi oleh ruang dan waktu (Zed, 2003:4-5).

Berdasarkan dengan hal tersebut diatas, maka pengumpulan data dalam penelitian dilakukan dengan menelaah dan/atau mengekplorasi beberapa Jurnal, buku, dan dokumen-dokumen (baik yang berbentuk cetak maupun elektronik) serta sumber-sumber data dan atau informasi lainnya yang dianggap relevan dengan penelitian atau kajian. Beberapa perspustakaan yang dikunjungi untuk memperoleh data antara lain: perpustakaan Universitas Negeri Yogyakarta, perpustakaan Universitas Gajah Mada, perpustakaan Wilayah DIY kesemuanya di Yogyakarta. Teknik analisis data dilakukan dengan melakukan crosscheck antar sumber pustaka yang diperoleh. 
Tuna satak bathi sanak ..... (Yuliyanto)

\section{Hasil dan Pembahasan}

Kearifan lokal adalam pengetahuan yang secara ekplisit muncul setelah melalui evolusi yang panjang beriringan dengan dinamika di suatu masyarakat dan lingkungannya dalam sistem lokal yang dialami bersama-sama. Proses evolusi ini bisa berjalan dalam waktu yang lama dan melekat dalam suatu masyarakat, yang dapat menjadi sumber energi potensial dari sistem pengetahuan kolektif masyarakat untuk hidup bersama secara dinamis dan damai. Kearifan lokal tidak sekedar menajdi acuan tingkah laku, tetapi lebih dari itu dapat mendominasi kehidupan masyarakat yang penuh keadaban (Widyanti, 2015)

Sibarani (2012) menjelaskan kearifan lokal sebagai kebijaksanaan atau pengetahuan asli dari suatu masyarakat yang berasal dari nilai luhur tradisi budaya untuk mengatur tatanan kehidupan masyarakat. Karsiwan, dkk (2017) menjelaskan bila kearifan lokal mampu memberikan sumbangsih pada masyarakat berupa pengetahuan lokal, keterampilan lokal, kecerdasan lokal, sumber daya lokal, proses sosial lokal, norma-etika lokal dan adat-istiadat lokal. Kearifan lokal adalah keunggulan yang dimiliki suatu masyarakat, meskipun nilai-nilai tersebut bersifat lokal namun esensi nilai yang dimiliki terkadang bersifat universal dan bisa juga dimiliki oleh masyarakat lain dalam bentuk dan istilah yang berbeda. Tuna satak bathi sanak merupakan salah satu kearifan lokal yang mengandung makna filosofis yang dalam dan bermakna bagi masyarakat Jawa. Nilai ini lebih banyak ditunjukkan oleh masyarakat yang berkegiatan dalam bidang perdagangan. Ungkapan ini dapat dikupas dari dua perspektif, yaitu perspektif sosial dan ekonomi.

Dikaji dari aspek sosial, tuna satak bathi sanak adadalah salah satu pengejawantahan cara hidup yang menekankan pada keselarasan, mengutamakan kerukunan antar warga masyarakat dan nilai gotong royong. Bin Rusli dan Talibo (2020) menuliskan nilai tuna satak bathi sanak sebagai salah satu gaya hidup muslim Yogyakarta kelas menengah bawah khususnya di Pasar Beringharjo. Tuna satak bathi sanak, bersama dengan nilai-nilai lokal lain seperti alon-alon waton kelakon yang bermakna berjalan pelan-pelan asalkan tercapai, nrima ing pandum yang berarti menerima dengan ikhlas rejeki yang diberikan Tuhan, mangan ora mangan asal ngumpul yang berarti berkumpul dengan keluarga lebih penting dibandingkan kelimpahan materi, dan sepi ing pamrih rame ing gawe yang berarti giat dan ikhlas bekerja tanpa mementingkan pamrih, banter tan mancengi dhuwur tan ngungkuli yang bermakna walaupun memiliki kehebatan dan kekuatan tetapi tetap rendah hati. 
Ungkapan-ungkapan dan adagium Jawa menegaskan bila masyarakat Jawa memegang teguh sikap-sikap yang mementingkan kepentingan umum, integrasi sosial, dengan menekan sifat egoisme dan kepentingan diri sendiri. Bin Rusli dan Talibo (2020) menjelaskan bila ungkapan-ungkapan Jawa ini mencerminkan bila masyarakat Jawa menjalankan pendekatan yang humanis, rasional, dan fungsional dalam bekerja.

Pendekatan humanis ditunjukkan dengan melibatkan unsur kemanusiaan dan nilai ketuhanan, bahwa manusia selalu akan saling membutuhkan. Pendekatan rasional tercermin dalam mengemukakan pendapat, merumuskan tujuan, serta mengarahkan implementasi. Disadari bila sistem pasar terjadi karena kausalitas, dan bukan terjadi secara alamian dengan sendirinya. Serta pendekatan fungsional, seperti bersikap bijak dalam memenuhi kebutuhan hidup. Sikap bijak dalam memenuhi kebutuhan hidup, menghindari perilaku materialistis dan keserakahan inilah yang dijunjung tinggi. Masyarakat Jawa secara prinsip menganggap bahwa banyaknya jumlah saudara ataupun kerabat itu dianggap lebih kaya dari pada mereka yang mempunyai harta benda. Dengan jumlah saudara dan kerabat yang banyak masyarakat Jawa menganggap bahwa segala urusan dan kesulitan akan mudah diselesaikan dengan cara gotong royong. Seperti kita ketahui bersama bahwa dalam kehidupan masyarakat Jawa, spirit gotong royong masih sangat kuat. Sikap entengan (ringan membantu) terlihat khususnya pada saat terjadi acara sosial, hajatan, orang sakit, ataupun warga yang meninggal. Seseorang yang dianggap entengan cenderung memiliki kesan baik, diterima oleh masyarakat dan akan lebih banyak dibantu oleh masyarakat di sekitarnya.

Pitoyo (2008) menjelaskan bila pada tuna satak bathi sanak menunjukkan bila masyarakat Jawa memegang teguh keharmonisan dalam kehidupan yang terkait dengan hubungannya dengan Tuhan dan sesama manusia. Mengingat istilah bebrayan agung sangat populer di masyarakat Jawa yang berarti keluarga besar, jadi orang lain yang tidak memiliki hubungan darah dianggap pula sebagai saudara. Sehingga kehidupan yang dijalani haruslah dijaga keharmonisasiannya, bila ada yang kekurangan dan kesulitan maka anggota masyarakat lain harus saling meringankan.

Mangkunegara IV seorang filsuf Jawa dalam Serat Wedhatama bait ke-29 memberikan petunjuk dalam konteks bisnis, dengan menerapkan tiga nilai penting (tri prakara) bagi kehidupan yang layak, yakni wirya, arta, dan wasis. Wirya, berarti orang harus memiliki keberanian yang cukup untuk melangkah dan meraih apa yang 
dicita-citakannya, apa yang ditargetkannya. Keberanian ini penting, karena banyak keinginan atau cita-cita kandas sebelum ditempuh disebabkan oleh tidak adanya keberanian untuk mewujudkannya (Pitoyo, 2008). Pendek kata, banyak rencana besar abortus karena ketidakberanian orang untuk merealisasikannya. Arta, arti sempitnya uang, sedangkan arti luasnya harta benda. Barang siapa masih hidup di dunia, dia tentu membutuhkan harta. Harta memang bukan segalanya, tetapi barang siapa tak berharta, miskin papa, maka celakalah hidupnya, bahkan bisa jatuh martabatnya. Harta itu tidak begitu saja jatuh dari langit, melainkan diusahakan, diupayakan, dicari, dikumpulkan, disimpan, dan dikelala dengan saksama. Dalam makna seperti inilah kegiatan bisnis mendapatkan tempatnya yang layak dalam format budaya Jawa. Kata kunci wasis, artinya cerdas, pandai, atau smart. Dengan perkataan lain, orang harus berilmu, agar hidupnya berguna, bisa mencari nafkah, tidak sengsara, dan terhormat. Dengan ilmu atau kecerdasan yang dimilikinya, orang dapat memiliki seribu satu peluang untuk meningkatkan taraf hidupnya. Ilmu diperlukan bagi kegiatan hidup apa saja, termasuk berbisnis. Jadi, dalam konteks bisnis, ajaran tri prakara ini merupakan tiga tiang penyangga atau fondasi yang penting.

Ajaran Mangkunegara IV yang lain terdapat dalam Serat Darmalaksita yang disebut Asta Gina, yang berupa 8 keutamaan yang penting (Pitoyo, 2008). Kata-kata kuncinya ialah (1) Panggautan. (2) rigen, (3) gemi, (4) nasiti, (5) petungan, (6) taberi tatanya, (7) nyegah kayun, (8) nemen ing seja. Panggautan, secara harfiah berarti pekerjaan. Orang hidup haruslah mengusahakan pekerjaan, apa saja, yang dapat memberi penghasilan, sesuai dengan perkembangan dan tuntutan zaman. Rigen berarti pandai mencari akal, kreatif, selalu mencari dan membuka peluang agar dapat mendatangkan pendapatan. Gemi, artinya pandai berhemat dan cermat dalam pengeluaran dalam pengelolaan usaha sehingga efisien. Nastiti berarti teliti dan berhati-hati dalam mengelola usaha agar tidak terjerumus dalam jurang kerugian. Petungan, secara harafiah berarti perhitungan. Dalam konteks ajaran Mangkunegara IV ini, perhitungan yang dimaksud bukan hanya berhitung dalam konteks bisnis semata, melainkan lebih luas lagi, yakni agar orang berhitung dengan cermat agar tidak terlena dengan godaan menuruti keinginan sesaat, tanpa memikirkan hari esok. Ini merupakan ajaran agar orang menjaga keberlanjutan bisnisnya agar tetap survival.

Lebih lajut dijelaskan oleh Zulfikar (2008) bila sikap hidup pedagang Jawa ini menunjukkan sikap tepo seliro (tenggang rasa). Rasa persaudaraan mencegah pedagang mematok harga tinggi pada pembelinya, dan bahkan menawarkan harga 
yang terlalu tinggi dibandingkan kualitas barang yang dijual. Masyarakat Jawa pada umumnya juga meyakini konsep nandur bakal ngunduh, atau siapa yang berbuat pasti mendapatkan ganjaran kelak di kemudian hari. Inilah yang menjadi pegangan, bahwa sikap-sikap yang ditunjukkan menunjukkan adanya dorongan dari nurani untuk menghindari perbuatan yang merugikan orang lain. Suranto (2015) juga menjelaskan bila tidak masalah mengalami kerugian sedikit harta, karena dari silaturahmi itu akan memperoleh keuntungan yang lebih besar, yaitu ikatan persaudaraan, ikatan famili, silaturahmi dan integrasi sosial. Integrasi sosial ini yang dalam keseharian banyak ditekankan masyarakat Jawa dalam berhubungan dengan anggota masyarakat yang lain. Sepertihalnya banyak diketahui bila masyarakat Jawa identik dengan sikap kehati-hatian dalam berkomunikasi, menghindari konflik, dan mengutamakan sopan santun.

Di sisi lain, disampaikan oleh Nawawi (2012) karena masyarakat Jawa sangat kuat memegang prinsip kerukunan antar warganya, menjadikan masyarakat Jawa menjadikannya sebagai motivasi kuat dalam bertindak menghindari konflik. Hal ini dilakukan karena ditakutkan bila terjadi pertengkaran antar saudara maka akan berakibat pada menjauhnya rejeki dan berkah. Ungkapan Jawa yang mencerminkan nilai ini adalah cecegilan iku ngadohake rejeki, atau pertengkaran menjauhkan rejeki. Masyarakat Jawa berpirnsip jangan sampai seseorang kehilangan teman atau pergaulan, jadi jangan sampai terjadi konflik dengan orang lain. Lebih lanjut Nawawi (2012) juga menjelaskan bila dalam ungkapan tuna satak bathi sanak terdapat ajaran bila manusia bahwa kelimpahan harta tidak ada artinya dibandingkan dengan kehilangan martabat sebagai manusia. Martabatnya sebagai manusia yang berhati baik, dermawan, senang menolong, dan menjaga persaudaraan jauh lebih berharga dibandingkan dengan jumlah materi yang dikorbankan dalam ungkapan tuna satak. Meskipun pada taraf tertentu tindakan menghindari konflik tidak selamanya baik dan benar, karena konflik adalah suatu keniscayaan dalam hubungan antar manusia. Namun masyarakat Jawa tentu tetap menjalaninya dengan motivasi lurus, bahwa kerukunan antar masyarakat adalah kunci kehidupan yang damai.

Dilihat dari aspek ekonomi, dijelaskan oleh Pitoyo (2008) tuna satak bathi sanak sering dikritik. Bila benar-benar dipraktekkan dalam perdagangan sehari-hari, maka kegiatan jual beli bisa menjadi kegiatan kedermawanan sosial (philanthropy). Kegiatan bisnis hakihatnya sangat berbeda dengan kegiatan sosial dan kegiatan kedermawanan. Kegiatan bisnis dijalankan dengan tujuan mendapatkan laba atau 
Tuna satak bathi sanak ..... (Yuliyanto)

keuntungan. Bahkan bisnis yang baik sering dipahami sebagai bisnis yang memberi keuntungan sebanyak-banyaknya bagi yang menjalankannya. Motivasi ekonomi memang bagi pedagang umunya terletak pada keinginan untuk mendapatkan keuntungan sebesar-besarnya. Namun pada masyarakat Jawa, ungkapan ini buka serta merta berseberangan dengan motivasi laba tersebut.

Bila dikaji dalam konteks bisnis yang sesungguhnya, Pitoyo (2008) menerangkan bila konsep tuna satak sesuai digunakan sebagai sarana promosi, terutama promosi produk baru. Dalam rangka promosi, mengurangi jumlah laba tidaklah masalah, yang utama adalah produk yang dijual dikenal dengan luas dulu oleh khalayak. Selanjutnya juga dijelaskan bila membangun jaringan atau network juga penting, karena di masa depan hal-hal yang darurat bisa menimpa pedagang dengan konsumennya. Keuntungan materiil bisa dinegosisasikan dengan keuntungan sosial yang bermakna lebih berarti, yaitu persaudaraan. Dengan kata lain, masyarakat Jawa memiliki pemahaman bila konsep keuntungan, atau kekayaan tidak selalu identik dengan uang atau materi, tetapi juga hubungan sosial dengan orang-orang yang lebih luas.

Kebahagiaan orang yang berdagang tidak selalu diukur dengan keuntungan berupa uang. Materi bagi masyarakat Jawa bukanlah segalanya, yang oleh para pedagang diwujudkan dalam kesediaan untuk menjual barang dengan harga sedikit lebih rendah dari nilai yang ditawarkannya. Hubungan baik dengan orang lain yang pada konteks ini adalah pembelinya juga dianggap sebuah keuntungan atau rejeki dalam bentuk yang berbeda. Ukuran kekayaan seseorang dijelaskan oleh Zulfikar (2008) tidak selalu ditentukan dengan banyaknya harta yang dimiliki. Manusia jawa merupakan sosok yang dapat menerima kondisi atau nasib yang terjadi dalam hidupnya dengan dilandasi rasa percaya pada kemurahan Tuhan sehingga semua hal yang terjadi dalam hidupnya diterima dengan jiwa narima ing pandum (menerima apa yang telah digariskan).

Nilai-nilai kearifan yang muncul dari ungkapan tuna satakbathi sanak merupakan sedikit cerminan perwujudan nilai-nilai yang secara umum dijunjung tinggi oleh masyarakat Jawa. Dijelaskan oleh Zulfikar (2008) bila sanak adalah konsep dasar neraca dalam perdagangan. Bathi sanak, atau tambah persaudaraan disini juga berarti tambag pelanggan. Karena pada dasarnya tidak ada pedagang yang nyaman dengan konsep merugi. Pedagang secara alamiah menginginkan keuntungan agar bisa mendapat keuntungan dan memenuhi kebutuhan hidupnya. Pada konsep tuna 
sathak, pedagang lebih mementingkan keberlanjutan usahanya, pelanggan yang telah memiliki hubungan baik dengan penjual akan datang berulang pada penjual tersebut. Pelanggan juga adalah aset potensial yang harapannya akan menghasilkan keuntungan dalam jangka panjang. Sehingga tuna satak bukanlah hal yang dianggap merugikan.

Sebagai salah satu kekayaan kearifan lokal masyarakat Jawa, nilai yang terkandung dalam tuna satak bathi sanak dapat diintegrasikan dalam pembelajaran IPS di jenjang sekolah, utamanya pada jenjang Sekolah Menengah Pertama (SMP). Pengintegrasian nilai-nilai kearifan lokal tidak berseberangan dengan amanah kurikulum, mengingat pada Kurikulum 2013 memasukkan nilai-nilai luhur berbasis kemasyarakatan sebagai orientasi pengembangan pembelajaran berbasis budaya masyarakat (Supardan, 2015). Selanjutnya Supardan (2015) menjelaskan bila Kurikulum 2013 pembelajaran dikemas secara tematik sebagai suatu pendekatan pembelajaran dengan mengaitkan, memadukan materi ajar dalam suatu topik perkembangan siswa serta kebutuhan dan tuntutan lingkungannya. Mengembangkan lebih lanjut kecerdasan ekologis yang terdapat pada rumusan kompetensi peduli lingkungan yang terdiri dari unsur-unsur karakter.

Unsur-unsur nilai karakter dirumuskan oleh Kementrian Pendidikan nasional (2010) berisikan 18 karakter yang akan ditanamkan pada siswa sebagai wujud upaya membangun karakter bangsa. Nilai katakter tersebut adalah religius, jujur, toleransi, disiplin, kerja keras, kreatif, mandiri, demokratis, rasa ingin tahu, semangat kebangsaan, cinta tanah air, menghargai prestasi, komunikatif, cinta damai, gemar membaca, peduli lingkungan, peduli sosial, dan tanggungjawab. Dengan landasan ini pembelajaran IPS bisa dikembanggkan dengan mengintegrasikan nilai kearifan lokal yang sesuai dengan satu atau beberapa karakter yang telah dirumuskan, juga dengan selaras dengan materi pembelajaran.

Sejalan dengan pendapat di atas, Supriatna (2016) menyampaikan bila diberlakukannya kurikulum 2013 memberi ruang bagi guru-guru IPS untuk dapat menjadikan nilai-nilai yang berkembang dalam masyarakat dimasukkan sebagai bagian dari pembelajaran di kelas. Nilai-nilai dalam masyarakat biasanya telah terwujud dalam bentuk-bentuk kebudayaan yang dimiliki masyarakat itu sendiri, salah satunya dalam kearifan lokal yang ditemui sehari-hari. Widyanti (2015) menjelaskan bila nilai-nilai dalam kearifan lokal bisa diintegrasikan dalam pembelajaran IPS dalam bentuk bahan ajar. Nilai kearifan lokal yang diintegrasikan 
Tuna satak bathi sanak ..... (Yuliyanto)

tentu adalah kearifan lokal yang memiliki keunikan dan nilai-nilai sosial yang harapannya bisa membantu siswa dalam melihat dan mempelajari makna suatu peristiwa dan mengaplikasikannya dalam kehidupan mereka sehari-hari.

Karsiwan, dkk (2017) menjelaskan bila integrasi kearifan lokal pada pembelajaran IPS dapat dilakukan dengan memasukkan nilai-nilai kearifan lokal pada materi yang diajarkan di kelas, sehingga diharapkan siswa menyadari akan keberandaan dan pentingnya nilai-nilai tersebut dan menginternalisasikannya dalam diri siswa. Lebih lanjut dijelaskan intergasi dilakukan dengan cara memilai nilai-nilai dalam kearifan lokal yang sesuai dengan amanat kurikulum. Nilai-nilai dalam ungkapan tuna satak bathi sanak seperti telah dijelaskan, mengandung utamanya mengandung nilai karakter gotong-royong dan kerja sama yag kuat, yang berhubungan secara langsung pada aspek kehidupan sosial dan ekonomi masyarakat.

Nilai-nikai karakter ini bisa disesuaikan dengan Kompetensi Inti dan Kompetensi Dasar 3.3 yang diajarkan pada pembelajaran IPS di Kelas VII. Pada siswa kelas VII, siswa diminta memahami konsep dan menjelaskan hasil analisis tentang konsep interaksi antara manusia dengan ruang sehingga menghasilkan berbagai kegiatan ekonomi (produksi, distribusi, konsumsi, permintaan, penawaran) dan interaksi antar ruang untuk keberlangsungan kehidupan ekonomi, sosial, dan budaya Indonesia. Materi ajar yang disampaikan meliputi aktivitas manusia dalam memenuhi kebutuhan. Kompetensi Dasar lain yang bisa diintegrasikan adalah KD 3.3 pada kelas IX, yaitu menganalisis ketergantungan antarruang dilihat dari konsep ekonomi (produksi, distribusi, konsumsi, harga, pasar) dan pengaruhnya terhadap migrasi prnduduk, transportasi, lembaga sosial dan ekonomi, pekerjaan, pendidikan, dan kesejahteraan masyarakat. Materi ajar yang disampaikan mengenai ketergantungan antarruang dan pengaruhnya terhadap kesejahteraan masyarakat.

Integrasi nilai-nilai kearifan lokal tuna satak bathi sanak dalam pembelajaran IPS dapat dilakukan dalam berbagai strategi. Widyati (2015) menjelaskan strategi mengintegrasikan nilai kearifan lokal pada pembelajaran IPS di kelas bisa dilakukan dengan mengajak siswa untuk langsung belajar di tengah masyarakat, menyaksikan bagaimana masyarakat mengimplementasikan nilai-nilai budayanya, mendiskusikan hasil pengamatan di dalam kelas, serta mencoba menggali potensi-potensi lain yang ada di lingkungan sekitar siswa sendiri. Strategi mengamati langsung atau dengan observasi di tengah masyarakat juga disampaikan oleh Hadi (2017) dengan cara mengajak siswa datang dan melihat langsung di lapangan, melihat bagaimana 
masyarakat desa mengimplementasikan nilai-nilai budayanya. Hasil dari observasi tersebut bisa dibawa ke dalam kelas untuk didiskusikan lebih jauh, dan siswa diajak untuk menggali adakah potensi-potensi lain yang ada di masyarakat untuk dapat dikembangkan beriringan dengan kearifan lokal yang dimaksud.

Strategi pengamatan di lapangan memiliki nilai lebih karena siswa harus menangkap dan mencatat sendiri kearifan lokal yang ada. Dengan siswa menemukan sendiri substansi yang dicari, siswa akan lebih memahami nilai-nilai yang dimaksud, bisa merasakan adakah nilai-nilai tersebut juga ada dalam kehidupan siswa seharihari. Sepulang dari observasi, siswa diminta mendiskusikan hasil observasinya di dalam kelas. Pada tahapan diskusi ini siswa bisa memberi penilaian, serta merefleksikan nilai-nilai yang ditemuinya, apa saja kelebihannya, apa saja kekurangannya, apakah kearifan lokal ini bisa bertahan, bagaimana mengoptimalkannya dalam kehidupan masyarakat yang lebih luas, ataupun diskusi dengantopik-topik lainnya. Pada kegiatan pembelajaran, siswa juga diminta untuk menggali potensi-potensi kearifan lokal yang lain yang bisa digali dalam konteks pembelajaran IPS. Dengan begitu pembelajaran IPS yang terintegrasi dengan kearifan lokal bisa terus dilakukan.

\section{Simpulan}

Tuna satak bathi sanak adalah ungkapan yang populer di kalangan masyarakat Jawa, khususnya masyarakat pedagang. Memiliki makna tidak masalah merugi sedikit, yang penting persaudaraan terjalin. Nilai ini telah menjadi kearifan lokal yang dipegang teguh oleh masyarakat Jawa sebagai salah satu identitas atau karakter masyarakat Jawa. Dalam prakteknya ungkapan ini bisa dilihat dari sisi sosiologis dan ekonomi. Pada aspek sosiologis, ungkapan ini menegaskan bila masyarakat Jawa menjunjung tinggi nilai gotong royong, tolong menolong, dan integrasi sosial.

Sementara pada aspek ekonomi ungkapan ini menegaskan bila masyarakat pedagang Jawa familiar dengan praktek perdagangan lebih baik mengambil untung sedikit-sedikit, tetapi produknya dikenal dengan luas, relasi dengan pelanggan yang kuat demi kelangsungan usaha yang lebih terjamin. Kearifan lokal ini dapat diintegrasikan dalam pembelajaran IPS di kelas-kelas khususnya pada materi yang menekankan pada kegiatan ekonomi masyarakat. Strategi integrasinya bisa dilakukan dengan cara membawa siswa mengobservasi penerapan nilai-niai kearifan lokal di masyarakat, kemudian mendiskusikannya di kelas, dan menggali potensi-potensi pengembangan kearifan lokal yang lainnya. 
Tuna satak bathi sanak ..... (Yuliyanto)

\section{Referensi}

Benedict, R. (1934). Patterns of culture. Houghton Mifflin Company.

Rusli, A. \& Talibo, I. (2020). Muslim Jawa: masjid, keraton, dan pasar. Potret Pemikiran, 24(1). 114-131. http://dx.doi.org/10.30984/pp.v24i1.1055

Daniah. (2016). Kearifan lokal (local wisdom) sebagai basis pendidikan karakter. PIONIR: Jurnal Pendidikan. http://dx.doi.org/10.22373/pjp.v5i2.3356

Dewantara, K., H. (1967). Kebudayaan (Bagian IIA). Majelis Luhur Persatuan Tamansiswa.

Hadi, E. S. (2017). Penerapan nilai-nilai kearifn lokal dalam budaya masyarakat desa Pakisrejo Tulungagung sebagai sumber pembelajaran IPS. INSPIRASI Jurnal Ilmu-Ilmu Sosial, 17(01). 254-250. http://dx.doi.org/10.29100/insp.v17i1.1570

Karsiwan, Pujiati, Rufaidah. (2017). Pembelajaran IPS berbasis nilai-nilai kearifan lokal pada siswa SMK farmasi cendikia farma husada. Jurnal Penelitian Humano. 8 (1), 1-13. http://dx.doi.org/10.33387/hjp.v8i1.482

Kemendiknas. (2011). Panduan pendidikan karakter. Pusat Kurikulum dan kebukuan Kemendiknas.

Nawawi. (2012). Dakwah keluarga: internalisasi nilai-nilai budi pekerti dalam keluarga Jawa. Ilmu dakwah: Academic Journal for Homiletic Studies. 6(2), 285-311. https://doi.org/10.15575/idajhs.v6i2.339

Pieterse, J. N. (2004). Globalization and culture: Global mélange. Rowman and Littlefield.

Pitoyo, D. (2008). Tuna satak bathi sanak (kearifan Jawa dalam etika bisnis). Jurnal Filsafat, 18 (2), 131-155. https://doi.org/10.22146/jf.3521

Poesponegoro, M., D. \& Notosusanto, N. (2010). Sejarah Nasional Indonesia jilid III. Balai Pustaka.

Sibarani, R. (2012). Kearifan lokal: Hakikat, peran, dan metode tradisi lisan. Asosiasi Tradisi Lisan (ATL).

Sumodiningrat, G. \& Wulandari, A. (2017). Pitutur luhur budaya Jawa. Penerbit Narasi.

Supardan, D. (2015). Pembelajaran IPS, filosofi, konsep, dan aplikasi. Penerbit Alfabeta.

Supardi \& Widiyastuti, A. (2014). Pemanfaatan laboratorium IPS SMP. JIPSINDO Jurnal pendidikan Ilmu pengetahuan Sosial Indonesia, 1(2). 141-160. https://doi.org/10.21831/jipsindo.v2i1.2886

Supardi, Saliman, \& Anik, A. (2016). Perbedaan kesiapan guru IPS SMP Kabupaten Sleman dalam implementasi pembelajaran IPS berbasis kurikulum 2013. JIPSINDO Jurnal pendidikan Ilmu Pengetahuan Sosial Indonesia, 3(2). 101121. https://doi.org/10.21831/jipsindo.v3i2.11694

Suranto, A. (2015). Implementasi teori komunikasi sosial budaya dalam pembangunan. INFORMASI Kajian Ilmu Komunikasi. 45(1), 65-72. https://doi.org/10.21831/informasi.v45i1.7771 
Widyanti, T. (2015). Penerapan nilai-nilai kearifan lokal dalam budaya masyarakat kampung adat Cireundeu sebagai sumber pembelajaran IPS. Jurnal pendidikan Ilmu Sosial. 24 (2), 161-166. https://doi.org/10.17509/jpis.v24i2.1452

Zed, M. (2003). Metode penelitian kepustakaan. Yayasan Obor Indonesia

Zulfikar. (2008). Menguak akuntabilitas dibalik tabir nilai kearifan budaya Jawa. Riset Akuntansi Dan Keuangan Indonesia (REAKSI). 7(2), 144-150. https://doi.org/10.23917//reaksi.v7i2.2613 